\title{
Antioxidant Activity of the Melanin Pigment Extracted from Aspergillus nidulans
}

\author{
Rita de Cássia R. Goncalves and Sandra Regina Pombeiro-Sponchiado* \\ Departamento de Bioquímica e Tecnologia Química, Instituto de Química de Araraquara, Universidade Estadual Paulista \\ "Júlio de Mesquita Filho"; Rua Prof. Francisco Degni, s/n, CP 355, CEP 14801-970, Araraquara, SP, Brazil. \\ Received May 6, 2004; accepted November 2, 2004
}

\begin{abstract}
Melanins are pigments of high molecular weight formed by oxidative polymerization of phenolic or indolic compounds. A number of fungi, including Aspergillus nidulans, produce pigments related or identical to melanin, which are located on cell walls or exist as extracellular polymers. The aim of the present study was to assess the antioxidant activity of synthetic melanin and of the pigment extracted from the mycelium and culture medium after growth of the highly melanized strain (MEL1) from A. nidulans. The ability of the melanin pigment to scavenge the oxidants $\mathrm{HOCl}$ and $\mathrm{H}_{2} \mathrm{O}_{2}$ was evaluated by inhibition of the oxidation of 5-thio-2-nitrobenzoic acid (TNB) using several melanin concentrations. The results showed that the pigment of the MEL1 strain competes with TNB for $\mathrm{H}_{2} \mathrm{O}_{2}$ and $\mathrm{HOCl}$, inhibiting TNB oxidation in a concentration-dependent manner. For the HOCl oxidant, this inhibition was comparable to that of synthetic melanin, whose $\mathrm{IC}_{50}$ values were quite close for both pigments. Thus, our results suggest that the melanin from A. nidulans is a potential HOCl scavenger and may be considered a promising material for the cosmetic industry for the formulation of creams that protect the skin against possible oxidative damage.
\end{abstract}

Key words fungi; melanin; pigment; antioxidant activity; Aspergillus nidulans

Melanins are black or brown pigments of high molecular weight formed by oxidative polymerization of phenolic or indolic compounds. They are found in organisms of all phylogenetic kingdoms, showing a broad spectrum of biological roles, including thermoregulation, chemoprotection, camouflage and sexual display. ${ }^{1}$

These pigments are not essential for fungal growth and development, but have been reported to act as "fungal armor" because of the ability of the polymer to protect these microorganisms against harmful environmental conditions such as UV radiation, temperature extremes, hydrolytic enzymes, metals or plant defense mechanisms. ${ }^{2-7)}$

The effect of melanin enhancing the survival of fungi can be mainly due to its function as an extracellular redox buffer which can neutralize oxidants generated by environmental stress. ${ }^{8)}$ Wang and Casadevall ${ }^{9)}$ observed that melanized Cryptococcus neoformans cells survived the action of nitrogen- and oxygen-derived oxidants approximately 10 -fold better than did non-melanized cells, suggesting that melanin contributes to virulence by protecting pathogens against free radicals generated immunologically. Studies on oxidative damage have shown that melanin in Wangiella dermatidis and Alternaria alternata appeared to confer cellular redox properties similar to those conferred by melanin upon $C$. neoformans. ${ }^{10,11)}$ Hoogduijn et al. ${ }^{12)}$ observed that melanin protects melanocytes and keratinocytes from the induction of DNA strand breaks by hydrogen peroxide, indicating that this pigment has an important antioxidant role in the skin.

In the last decades, skin cancer has been increasing alarmingly due to chronic exposure to UV light and certain environmental chemicals. The major cause of DNA damage induced by these agents is the production of reactive oxygen species (ROS) and free radicals. ${ }^{13,14)}$ Substances acting as antioxidants, i.e., reactive oxygen and radical scavengers, protect cells from ROS-mediated DNA damage, which can result in mutation and subsequent carcinogenesis. ${ }^{15,16)}$ Various studies have demonstrated that melanins act as antioxidants and suggest its use as a raw cosmetic material to minimize light- and toxin-induced tissue destruction. ${ }^{1,17)}$ In this context, fungal melanin is of considerable biotechnological interest because it can be produced for low cost on a large scale compared with industrially-produced melanin, making its use as an antioxidative agent in cosmetic formulations economically advantageous. Taking this information into account, in the present study we assessed the antioxidant activity of the melanin pigment extracted from $A$. nidulans fungus in order to determine its possible utilization in the pharmaceutical industry.

\section{RESULTS AND DISCUSSION}

We first assessed the antioxidant activity of synthetic melanin, which was used as a control in the study because of its recognized activity as a reactive oxygen species (ROS) scavenger ${ }^{5}$ As shown in Tables 1 and 2, the oxidation of 5thio-2-nitrobenzoic acid (TNB) by hydrogen peroxide $\left(\mathrm{H}_{2} \mathrm{O}_{2}\right)$ and hypochlorous acid $(\mathrm{HOCl})$ resulted in a decrease of the absorbance to $412 \mathrm{~nm}$ compared to TNB alone, whose absorbance value was $0.491 \pm 0.0438$ (data not shown). However, in the presence of synthetic melanin there was an increase of absorbance at $412 \mathrm{~nm}$ proportional to melanin concentration (Tables 1,2), indicating that the melanin reacts with $\mathrm{H}_{2} \mathrm{O}_{2}$ or $\mathrm{HOCl}$ and reduces the amount of TNB to be oxidized. In $100 \mu \mathrm{g}$ melanin $/ \mathrm{ml}$, only $25.65 \%$ and $10.93 \%$ of TNB was oxidized, respectively, by $\mathrm{H}_{2} \mathrm{O}_{2}$ and $\mathrm{HOCl}$ (Tables $1,2)$. Therefore, our results confirm the antioxidant properties of the synthetic melanin for the biological oxidants used.

As observed for the synthetic melanin, the incubation of $\mathrm{H}_{2} \mathrm{O}_{2}$ and $\mathrm{HOCl}$ with pigment extracted from the culture medium and from mycelium of the MEL1 strain also showed that this pigment inhibits TNB oxidation in a concentrationdependent manner, i.e., the lowest percentage of oxidized TNB was obtained in the presence of $100 \mu \mathrm{g}$ melanin/ml (Tables 3 -6). These results indicate that the pigment obtained 
Table 1. Effect of Synthetic Melanin on $\mathrm{H}_{2} \mathrm{O}_{2}$-Dependent TNB Oxidation

\begin{tabular}{ccc}
\hline \hline TNB plus $\mathrm{H}_{2} \mathrm{O}_{2}$ and melanin & $\mathrm{A} 412^{a)}$ & Oxidized TNB (\%) \\
\hline $0(\mu \mathrm{g} / \mathrm{ml})$ & $0.065 \pm 0.001$ & 100 \\
$25(\mu \mathrm{g} / \mathrm{ml})$ & $0.158 \pm 0.004$ & $78.11^{*}$ \\
$50(\mu \mathrm{g} / \mathrm{ml})$ & $0.199 \pm 0.006$ & $68.47^{*}$ \\
$100(\mu \mathrm{g} / \mathrm{ml})$ & $0.381 \pm 0.04$ & $25.65^{*}$ \\
\hline
\end{tabular}

a) values are the means \pm S.D. of three independent measurements. * Values were significantly different $(p<0.05)$ from the control TNB plus $\mathrm{H}_{2} \mathrm{O}_{2}(100 \%)$

Table 2. Effect of Synthetic Melanin on HOCl-Dependent TNB Oxidation

\begin{tabular}{ccc}
\hline \hline TNB plus HOCl and melanin & A412 & Oxidized TNB $(\%)$ \\
\hline $0(\mu \mathrm{g} / \mathrm{ml})$ & $0.069 \pm 0.001$ & 100 \\
$25(\mu \mathrm{g} / \mathrm{ml})$ & $0.110 \pm 0.003$ & 90.26 \\
$50(\mu \mathrm{g} / \mathrm{ml})$ & $0.128 \pm 0.005$ & $85.98^{*}$ \\
$100(\mu \mathrm{g} / \mathrm{ml})$ & $0.444 \pm 0.02$ & $10.93^{*}$
\end{tabular}

a) Values are the means \pm S.D. of three independent measurements. $*$ Values were significantly different $(p<0.05)$ from the control TNB plus $\mathrm{HOCl}(100 \%)$.

Table 3. Effect of the Pigment Obtained from the Culture Medium for the MEL1 Strain on $\mathrm{H}_{2} \mathrm{O}_{2}$-Dependent TNB Oxidation

\begin{tabular}{ccc}
\hline \hline TNB plus $\mathrm{H}_{2} \mathrm{O}_{2}$ and pigment & \multicolumn{1}{c}{$\mathrm{A} 412^{a)}$} & Oxidized TNB (\%) \\
\hline $0(\mu \mathrm{g} / \mathrm{ml})$ & $0.065 \pm 0.001$ & 100 \\
$25(\mu \mathrm{g} / \mathrm{ml})$ & $0.104 \pm 0.002$ & 90.82 \\
$50(\mu \mathrm{g} / \mathrm{ml})$ & $0.129 \pm 0.004$ & $84.94^{*}$ \\
$100(\mu \mathrm{g} / \mathrm{ml})$ & $0.215 \pm 0.02$ & $64.70^{*}$
\end{tabular}

a) Values are the means \pm S.D. of three independent measurements. $*$ Values were significantly different $(p<0.05)$ from the control TNB plus $\mathrm{H}_{2} \mathrm{O}_{2}(100 \%)$.

Table 4. Effect of the Pigment Extracted from the Mycelium of the MEL1 Strain on $\mathrm{H}_{2} \mathrm{O}_{2}$-Dependent TNB Oxidation

\begin{tabular}{ccc}
\hline \hline TNB plus $\mathrm{H}_{2} \mathrm{O}_{2}$ and pigment & $\mathrm{A} 412^{a)}$ & Oxidized TNB (\%) \\
\hline $0(\mu \mathrm{g} / \mathrm{ml})$ & $0.065 \pm 0.001$ & 100 \\
$25(\mu \mathrm{g} / \mathrm{ml})$ & $0.095 \pm 0.002$ & 92.94 \\
$50(\mu \mathrm{g} / \mathrm{ml})$ & $0.107 \pm 0.005$ & 90.11 \\
$100(\mu \mathrm{g} / \mathrm{ml})$ & $0.163 \pm 0.004$ & $76.94^{*}$
\end{tabular}

a) Values are the means \pm S.D. of three independent measurements. $*$ Values were significantly different $(p<0.05)$ from the control TNB plus $\mathrm{H}_{2} \mathrm{O}_{2}(100 \%)$.

Table 5. Effect of the Pigment Obtained from the Culture Medium for the MEL1 Strain on HOCl-Dependent TNB Oxidation

\begin{tabular}{ccc}
\hline \hline TNB plus HOCl and pigment & A412 & Oxidized TNB (\%) \\
\hline $0(\mu \mathrm{g} / \mathrm{ml})$ & $0.069 \pm 0.001$ & 100 \\
$25(\mu \mathrm{g} / \mathrm{ml})$ & $0.298 \pm 0.02$ & $45.6^{*}$ \\
$50(\mu \mathrm{g} / \mathrm{ml})$ & $0.367 \pm 0.01$ & $29.21^{*}$ \\
$100(\mu \mathrm{g} / \mathrm{ml})$ & $0.459 \pm 0.02$ & $7.36^{*}$ \\
\hline
\end{tabular}

a) values are the means \pm S.D. of three independent measurements. $*$ Values were significantly different $(p<0.05)$ from the control TNB plus $\mathrm{HOCl}(100 \%)$.

from the MEL1 strain competed with TNB for $\mathrm{H}_{2} \mathrm{O}_{2}$ and $\mathrm{HOCl}$ and, therefore, had a scavenging activity on the oxidants tested. Studies with $A$. fumigatus and $A$. nidulans also showed that conidial pigments of both species are important for the protection of conidia against oxidative damage. ${ }^{18,19)}$

By comparing the results obtained with the two oxidants tested, it could be seen that the pigment of the MEL1 strain was a more efficient $\mathrm{HOCl}$ scavenger because the $\mathrm{IC}_{50}$ value
Table 6. Effect of the Pigment Extracted from the Mycelium of the MEL1 Strain on HOCl-Dependent TNB Oxidation

\begin{tabular}{ccc}
\hline \hline TNB plus $\mathrm{HOCl}$ and pigment & $\mathrm{A} 412^{a)}$ & Oxidized TNB (\%) \\
\hline $0(\mu \mathrm{g} / \mathrm{ml})$ & $0.069 \pm 0.001$ & 100 \\
$25(\mu \mathrm{g} / \mathrm{ml})$ & $0.211 \pm 0.02$ & $66.27^{*}$ \\
$50(\mu \mathrm{g} / \mathrm{ml})$ & $0.278 \pm 0.04$ & $50.35^{*}$ \\
$100(\mu \mathrm{g} / \mathrm{ml})$ & $0.471 \pm 0.01$ & $4.51^{*}$
\end{tabular}

a) Values are the means \pm S.D. of three independent measurements. $*$ Values were significantly different $(p<0.05)$ from the control TNB plus $\mathrm{HOCl}(100 \%)$.

Table 7. Scavenging Activity of Synthetic Melanin and Pigment Obtained from MEL1 Strain on HOCl- and $\mathrm{H}_{2} \mathrm{O}_{2}$-Dependent TNB Oxidation

\begin{tabular}{llr}
\hline \multicolumn{1}{c}{ Scavenger } & Oxidant & \multicolumn{1}{c}{$\mathrm{IC}_{50}{ }^{a}{ }^{\circ}$} \\
\hline Synthetic melanin & $\mathrm{H}_{2} \mathrm{O}_{2}$ & $57.91 \pm 0.87$ \\
Synthetic melanin & $\mathrm{HOCl}$ & $56.89 \pm 0.34$ \\
MEL1 pigment (culture medium) & $\mathrm{H}_{2} \mathrm{O}_{2}$ & $121.87 \pm 1.12$ \\
MEL1 pigment (culture medium) & $\mathrm{HOCl}$ & $31.16 \pm 0.26$ \\
MEL1 pigment (mycelium) & $\mathrm{H}_{2} \mathrm{O}_{2}$ & $186.17 \pm 4.91$ \\
MEL1 pigment (mycelium) & $\mathrm{HOCl}$ & $40.57 \pm 0.36$ \\
\hline
\end{tabular}

a) Values are the means \pm S.D. of three independent measurements.

was much lower in the presence of $\mathrm{HOCl}$ than in the presence of $\mathrm{H}_{2} \mathrm{O}_{2}$ (Table 7). Jacobson et al. ${ }^{11)}$ also observed that the melanin of Cryptococcus neoformans and Wangiella dermatidisi neutralized more $\mathrm{HOCl}$ than $\mathrm{H}_{2} \mathrm{O}_{2}$. Among the reasons for these results, the most important is that reaction of $\mathrm{H}_{2} \mathrm{O}_{2}$ with melanin requires an alkaline condition. ${ }^{20)}$ This condition was not obtained here with the pigment from the MEL1 strain, whose reaction $\mathrm{pH}$ remained at 5.8 (data not shown) probably due to the acid conditions used for the extraction of this pigment.

Our results also showed that the pigment extracted from the MEL1 strain is a potential HOCl scavenger because the magnitude of the protection it provides was comparable to that of the synthetic melanin, with $\mathrm{IC}_{50}$ value of the pigment from the MEL1 strain being quite close to that for synthetic melanin (Table 7). In biological systems, $\mathrm{HOCl}$ is regarded as the most toxic and abundant oxidant and capable of doing considerable tissue damage, because it rapidly attacks a wide range of physiologically relevant molecules (such as amines, amino acids, nucleotides) and can also generate other very reactive oxidizing species like singlet oxygen and hydroxyl radical. ${ }^{21)}$ In this context, our results indicate that the melanin from Aspergillus nidulans can be viewed as a promising source for future practical applications in the cosmetic industry as a component of creams that protect the skin from possible oxidative damage.

\section{EXPERIMENTAL}

Strains and Growth Conditions The present study was carried out with highly melanized mutant (denominated MEL1) of Aspergillus nidulans. This strain was grown in $250 \mathrm{ml}$ Erlenmeyer flasks containing $100 \mathrm{ml}$ of liquid minimal medium ${ }^{22}$ using $55 \mathrm{~mm}$ glucose as the carbon source and $70 \mathrm{~mm}$ sodium nitrate as the nitrogen source; it was inoculated with approximately $10^{6}$ conidia/ $\mathrm{ml}$ and incubated at $37^{\circ} \mathrm{C}$ in a rotary shaker at $220 \mathrm{rpm}$ for $72 \mathrm{~h}$. Thereafter, the mycelium was collected by vacuum filtration and the melanin 
present in the mycelium and culture medium was then extracted.

Melanin Extraction The melanin in the culture medium was extracted by the method of Paim et al. ${ }^{23)}$ The culture solutions were acidified to $\mathrm{pH} 1.5$ with $6 \mathrm{~N} \mathrm{HCl}$ and allowed to stand overnight to precipitate the polymer. The melanin precipitates were recovered by centrifugation at $4500 \boldsymbol{g}$ for $15 \mathrm{~min}$ and lyophilized. The amount of produced pigment was approximately $175 \mu \mathrm{g}$ per $\mathrm{ml}$ of medium.

Extraction and purification of melanin from the mycelium were performed according the procedure described by Sava et al. ${ }^{24)}$ with minor modifications. First, the mycelial mass was treated with $2 \mathrm{M} \mathrm{NaOH}$, pH 10.5 , for $36 \mathrm{~h}$. Thereafter, the mixture was centrifuged at $4000 \mathrm{~g}$ for $15 \mathrm{~min}$ and the supernatant was acidified with $2 \mathrm{M} \mathrm{HCl}$ to $\mathrm{pH} 2.5$, incubated for $2 \mathrm{~h}$ at room temperature, and centrifuged at $4000 \boldsymbol{g}$ for $15 \mathrm{~min}$. The precipitate obtained was purified by acid hydrolysis using $6 \mathrm{M} \mathrm{HCl}$ at $100^{\circ} \mathrm{C}$ for $2 \mathrm{~h}$ to remove carbohydrates and proteins and treated with an organic solvent (chloroform, ethyl acetate and ethanol) to wash away lipids. The precipitate was then dried at room temperature, re-dissolved in $2 \mathrm{M}$ $\mathrm{NaOH}$ and centrifuged at $4000 \boldsymbol{g}$ for $15 \mathrm{~min}$. The supernatant was precipitated by the addition of $1 \mathrm{M} \mathrm{HCl}$, washed with distilled water and lyophilized. This procedure yielded about $94.5 \mu \mathrm{g}$ of pigment per mg mycelial mass.

Antioxidant Activity The antioxidant activity of the melanin extracted from mycelium and culture medium after growth of the MEL1 mutant was determined by a simple and rapid method described by Ching et al. ${ }^{25}$ ) This method is based on the ability of a substance (scavenger) to inhibit the oxidation of 5-thio-2-nitrobenzoic acid (TNB) to 5,5' dithio2-nitrobenzoic acid (DTNB) in the presence of the oxidants $\mathrm{HOCl}$ and $\mathrm{H}_{2} \mathrm{O}_{2}$. The ability of the pigment to scavenge $\mathrm{HOCl}$ and $\mathrm{H}_{2} \mathrm{O}_{2}$ was determined by the concentration of $\mathrm{TNB}$, as quantified by absorbance at $412 \mathrm{~nm} .^{25}$ )

TNB was synthesized by adding $20 \mathrm{~mm}$ sodium borohydride and then added to a $1 \mathrm{~mm}$ DTNB solution in $50 \mathrm{~mm}$ potassium phosphate buffer, $\mathrm{pH} 6.6$, containing 5 mм EDTA. The solution was incubated at $37^{\circ} \mathrm{C}$ for $30 \mathrm{~min}$ and $\mathrm{TNB}$ concentration was determined by absorbance at $412 \mathrm{~nm}$ using the molar absorption coefficient of $13600 \mathrm{M}^{-1} \mathrm{~cm}^{-1}$.

In the assay for hypochlorous acid scavenging, $\mathrm{HOCl}$ was first produced from sodium hypochlorite at $\mathrm{pH} 12$ in potassium phosphate buffer $10 \mathrm{~mm} \mathrm{pH} 7.4$ containing $\mathrm{NaCl}$ $0.85 \%$; $\mathrm{HOCl}$ concentration was determined spectrophotometrically at $295 \mathrm{~nm}$ using the molar absorption coefficient of $350 \mathrm{M}^{-1} \mathrm{~cm}^{-1}$. For assay, $20 \mu \mathrm{M} \mathrm{HOCl}$ was incubated for $5 \mathrm{~min}$ in the presence or absence of the scavenger (melanin pigment) and $40 \mu \mathrm{M}$ TNB solution (described above) was then added in a final volume of $1 \mathrm{ml}$. The synthetic melanin (Sigma ref. 8631) and the melanin extracted from the MEL1 strain were used at concentrations of 25,50 and $100 \mu \mathrm{g} / \mathrm{ml}$.

In the assay for hydrogen peroxide scavenging, the solution of $\mathrm{H}_{2} \mathrm{O}_{2}$ was previously prepared in milli-Q water and the $\mathrm{H}_{2} \mathrm{O}_{2}$ concentration was calculated by absorbance measured at $230 \mathrm{~nm}$ using the molar absorption coefficient of $80 \mathrm{M}^{-1} \mathrm{~cm}^{-1}$. For the assay, $80 \mu \mathrm{M} \mathrm{H}_{2} \mathrm{O}_{2}$ solution was incubated for $10 \mathrm{~min}$ in the presence or absence of the scavenger (melanin pigment) and $40 \mu \mathrm{M}$ TNB solution (described above) was then added in a final volume of $1 \mathrm{ml}$. The synthetic melanin (Sigma ref. 8631) and the melanin extracted from the MEL1 strain were used at concentrations of 25,50 and $100 \mu \mathrm{g} / \mathrm{ml}$.

The $\mathrm{IC}_{50}$ (inhibitory concentration, 50\%) was determined using linear regression analysis of the dose-response curves (melanin concentration versus absorbance at $412 \mathrm{~nm}$ ).

Statistical Analysis The parameters were reported as mean \pm S.D. Statistical analysis was performed by analysis of variance (ANOVA). Differences were considered significant at $p<0.05$.

Acknowledgement This study was supported by a grant from CAPES to RCRG.

\section{REFERENCES}

1) Riley P. A., Int. J. Biochem., Cell Biol., 29, 1235-1239 (1997).

2) Bell A. A., Wheeler M. H., Ann. Rev. Phytopathol., 24, 411-451 (1986).

3) Fogarty R. V., Tobim J. M., Enzyme Microb. Technol., 19, 311-317 (1996).

4) Butler M. J., Day A. W., Can. J. Microbiol., 44, 1115-1136 (1998).

5) Jacobson E. S., Clin. Microbiol. Rev., 13, 708-717 (2000).

6) Rosas A. L., Macgill R. S., Nosanchuk J. D., Kozel T. R., Casadevall A., Clin. Diagn. Lab. Immunol., 9, 144-148 (2002).

7) Gómez B., Nosanchuk J. D., Curr. Opin. Infect. Dis., 16, 91-96 (2003).

8) Jacobson E. S., Tinnell S. B., J. Bacteriol., 175, $7102-7104$ (1993).

9) Wang Y., Casadevall A., Infect. Immun., 62, 3004-3007 (1994).

10) Schnitzler N., Peltroche-Llacsahuanga H., Bestier N., Zündorf J., Lütticken R., Haase G., Infect. Immun., 67, 94-101 (1999).

11) Jacobson E. S., Hove E., Emery H. S., Infect. Immun., 63, 4944-4945 (1995).

12) Hoogduijn M. J., Cemeli E., Anderson D., Wood J. M., Thody A. J., Br. J. Dermatol., 148, 867 (2003).

13) Kelrer J. P., Crit. Rev. Toxicolog., 23, $21-48$ (1993).

14) Grimbaldeston M. A., Geczy C. L., Tedla N., Finlay-Jones J., Hart P. H., J. Invest. Dermatol., 121, $1168-1174$ (2003).

15) Halliwell B., Biochem. Pharmacol., 49, 1341-1349 (1995).

16) Lopaczynski W., Zeisel S. H., Nutrition Res., 21, 295-307 (2001).

17) Kalka K., Mukhtar H., Turowski-Wanke A., Merk H., Skin Pharmacol. Appl. Skin Physiol., 1, 143-149 (2000).

18) Jahn B., Koch A., Boukhallouk F., Lortz J., Langfelder K., Warner G., Brakhage A. A., Infect. Immun., 68, 3736-3739 (2000).

19) Jahn B., Koch A., Schimidt A., Wanner G., Gehringer H., Sucharit B. Brakhage A. A., Infect. Immun., 65, 5110-5117 (1997).

20) Wolfram L. J., J. Soc. Cosmet. Chem., 21, 875-900 (1970).

21) Lapenna D., Cuccurullo F., Gen. Pharmac., 27, 1145-1147 (1996).

22) Cove D. J., Biochim. Biophys. Acta, 113, 51-56 (1966).

23) Paim S., Linhares L. F., Mangrich A. S., Martim J. P., Biol. Fertil. Soils, 10, 72-76 (1990).

24) Sava V. M., Galkin B. N., Hong M. Y., Yang P. C., Huang G. S., Food Res. Int., 34, 337-343 (2001).

25) Ching T., Jong J., Bast A., Anal. Biochem., 218, 377-381 (1994). 